\title{
REPRESENTACIONES Y SUS IMPACTOS: el CASO de los lacandones en la Selva Lacandona
}

\author{
Tim Trench
}

\section{Introducción}

$\mathrm{P}$ ara el grupo de gente que no rebasa una población de 850 personas, los lacandones de la Selva Lacandona, Chiapas, han sido objeto de un número extraordinario de representaciones desde su "descubrimiento" a finales del siglo XVIII. Las representaciones se encuentran en todo tipo de medios, desde relatos de viajeros y etnólogos sobre la región hasta audiograbaciones, fotografías y películas, incluyendo un "documental/ficción" titulado Cascabel (Raúl Araiza, 1976). ${ }^{1}$ Más recientemente se han producido numerosas videograbaciones dedicadas a los lacandones, además, una búsqueda en Internet produce cuantiosos resultados. ${ }^{2}$ Los lacandones tienen su "propia" página web: Hach Winik Home Page, y existe un CD-Rom dedicado exclusivamente a ellos y su cultura: Memoria Lacandona (Na-Bolom/ECOsur, 2001).

Respecto a las representaciones escritas, Roberto Bruce - antropólogo norteamericano que estudió a los lacandones durante tres décadas - declaró hace más de veinte años que existían más publicaciones sobre los lacandones que individuos - estimando que la población en ese entonces era alrededor de 400

Tim Trench, Universidad Autónoma de Chapingo, Chiapas; México. personas - (Perera y Bruce, 1982: 14). Desde esas fechas se han producido todavía bastantes escritos sobre este grupo étnico, entre ellos varias monografías antropológicas, artículos académicos y periodísticos en revistas de diverso tipo, por no mencionar un sinfín de tesis. Aunado a esto, desde que las primeras avionetas aterrizaron en las comunidades lacandonas - 1940/ 1950 - , nuestros protagonistas han sido objeto del turismo internacional. De igual forma, los turistas que visitan las poblaciones lacandonas en la selva, invariablemente vuelven a sus casas con imágenes de esta gente plasmadas en fotografías o videograbaciones.

Sin lugar a duda, entonces, los lacandones siguen ejerciendo una fascinación notable tanto entre los frecuentes visitantes - sean turistas o investigadoresque llegan a esta región selvática (en su mayoría de origen extranjero) y entre aquellos mexicanos que no conocen la región pero han sido expuestos a suficientes imágenes de lacandones en la televisión o en los periódicos como para poder reconocer la "marca registrada" de este pequeño grupo indígena: su cabello largo y sus túnicas blancas. Esta fascinación y la proliferación de representaciones (escritas y visuales), se deben a causas predecibles. Como ha comentado Juan Pedro Viqueira, generalmente se ha percibido a los lacandones como el grupo "más indígena” de Chiapas, e incluso de toda 
la República (1995). Tal representación, a pesar de su esencialismo — como si la 'indigeneidad' fuera algo que se pudiera medir- tiene algo de fundamento. Aunque el aislamiento de los lacandones hasta mediados del siglo xx ha sido exagerado, al final de cuentas su historia colonial es distinta a la de sus vecinos indígenas de la selva y a los demás grupos indígenas en Chiapas. El problema con las representaciones de los lacandones siempre ha sido el mismo: ¿cómo describir la historia única de este grupo sin caer en el exotismo eurocéntrico que suele caracterizar a las representaciones de "ex primitivos"?

Argumento en el presente artículo que estas representaciones siguen siendo de carácter notablemente contradictorio. Si en el pasado los lacandones eran, a la vez, "salvajes" y "señores de un inmenso reino" (Blom y Duby, 1955: 156), estas contradicciones actualmente se expresan en su imagen como un grupo corrompido por el gobierno, el materialismo y el protestantismo, por un lado; y como un pueblo a punto de esfumarse, portador de sabidurías arcaicas, por el otro. Las representaciones "positivas" de este pequeño grupo les ofrecen ventajas claras a corto plazo, confiriendo cierto capital simbólico y político en sus relaciones con foráneos y en sus diversas luchas, además de variados beneficios económicos. Pero, a final de cuentas, es cuestionable si su imagen como pueblo "originario" y conservacionista "innato" les ayude en el largo plazo, ya que forma parte de un discurso fundamentalmente colonialista y puede limitar las oportunidades de las comunidades lacandonas a decidir su futuro y definir el carácter de su inserción en la sociedad nacional.

\section{Antecedentes}

Los lacandones son un grupo indígena maya. Representan una de las minorías étnicas más pequeñas de México y del mundo. Hasta mediados del siglo pasado, los lacandones se encontraban dispersos por la selva en asentamientos familiares o "acríbales" con nula organización política más allá de la familia extendida: era una sociedad acéfala. Este minúsculo grupo humano a la vez se puede dividir en dos subgrupos, el meridional y el septentrional, ambos demuestran leves distinciones culturales y lingüísticas (veáse Boremanse, 1998). Actualmente, la gran mayoría de los lacandones se encuentra concentrada en tres centros de población: Lacanjá Chansayab, Nahá y Metsabok. Debido a su patrón de asentamiento, hasta la década de 1970 el contacto con el Estado había sido mínimo; por un lado, su contacto foráneo se limitó a arqueólogos, antropólogos y turistas —encuentros generalmente vistos por los lacandones como benéficos-, por el otro con monteros, chicleros y grupos indígenas colonizadores — contactos percibidos negativamente en ocasiones-. ${ }^{4}$ Mucho cambió en 1972 cuando 66 familias lacandonas se volvieron beneficiarias de las 614321 hectáreas correspondientes a la llamada Comunidad "Zona Lacandona”, (CZL), otorgándoles este territorio según una lógica de restitución basada en su "posesión continua, pública, pacífica y a título de dominio de los terrenos comunales desde tiempo inmemorial" (Diario Oficial, 6/3/72: 10). Este decreto presidencial libró un sinfín de conflictos agrarios en la región, principalmente porque el polígono de este enorme territorio se impuso - total o parcialmentesobre 40 comunidades ya existentes, de las cuales 17 tenían dotaciones anteriores a la fecha del decreto de la CZL (véase De Vos, 2002: 114-117).

En 1979, 26 asentamientos choles y tzeltales lograron el reconocimiento de sus derechos agrarios y se volvieron comuneros, igual que los lacandones, en la CZL (Diario Oficial, 8/3/79). Sin embargo, a pesar de esta concesión por parte del gobierno — resultado de una lucha emprendida por dichos indígenas choles y tzeltales- el desenvolvimiento conflictivo del decreto de 1972 sigue y es hasta hoy evidenciado en el más reciente esfuerzo por parte del gobierno federal de 
"regularizar" la tenencia de la tierra en la Selva Lacandona, a través de una política de reubicaciones, regularizaciones e indemnizaciones. ${ }^{5}$

Estos hechos históricos son de relevancia para la presente discusión porque el tono de muchas de las representaciones de los lacandones cambió después de 1972. El ceder los derechos agrarios a los lacandones ha condicionado, de modo importante, la manera en que se habla de este grupo, particularmente en elámbito de la investigación agropolítica y entre los pobladores indígenas de la región, quienes no fueron incluidos en la CZL. Como ha comentado Jan de Vos, el decreto de 1972 convirtió a los lacandones en "hijos predilectos del régimen" —aludiendo al título del famoso libro de Arturo Warman-y causó un grave deterioro en las relaciones con sus nuevos vecinos indígenas (2002: 114).

Las críticas a este decreto - que siguen actualmente - han implicado, en algunos casos, una crítica notable hacia los propios lacandones por haberse vuelto "peones" de la política agraria del Estado y clientes corporativistas del Partido Revolucionario Institucional, PRI. Por ejemplo, a finales de la década de 1970, Gerardo Garfías y Marta Turok, en un artículo titulado "Los lacandones: un mito de la Reforma Agraria", sostuvieron que no se podía explotar — y destruir — la selva "sin que la selva tuviese un dueño que 'permitiera' hacerlo ¡y qué mejor que 66 lacandones, por demás "marginados'!" Los autores terminan su artículo comentando que el "desarrollo del capitalismo ha llegado a corromper e imprimir su sello a los supuestos lacandones, a pesar de los lamentos de románticos que, con aire melancólico, han querido escudar su visión colonizadora ante grupos indígenas" (1983: 446-7). Últimamente, el periódico La Jornada ha hablado del "factor lacandón" y su "secuestro histórico por el poder" (p. ej. 18/3/02).

\section{Las representaciones: causa y efecto}

Aparte de analizar los intereses, posicionamientos y discursos que inciden en la generación y la articulación de ciertas imágenes sobre un determinado grupo humano, existen dos aspectos clave referentes a la discusión de estas "representaciones". El primero trata del efecto tangible que tienen las mismas en las subjetividades dentro del grupo —es decir, su "autoimagen"-, las relaciones interétnicas locales, la relación del grupo con el gobierno, o el impacto de estas representaciones en su capital político-simbólico en diversas luchas. Por ejemplo, una representación antropológica —en forma etnográfíca — no pareciera tener tanta influencia como una nota periodística por el simple hecho de que no tanta gente suele leer etnografías. Obviamente, las representaciones en los medios masivos de comunicación pueden tener una incidencia más significativa por su más amplia cobertura y difusión entre la población. La importancia de estas imágenes reside en su extensa difusión y su potencial para afectar la "opinión pública". Mientras que la esporádica nota periodística o un reportaje aislado tal vez no tengan mucha secuela, en cambio la repetición de un acontecimiento, una postura o un enfoque, a veces poco respaldado en la investigación seria, puede tener un efecto "cumulativo" en forjar opinión pública.

A la vez, es necesario reconocer que estudios académicos pueden incurrir en estas fuentes más difundidas. Como veremos en el presente artículo, esto ha sido ejemplo en años recientes con la popularización de hipótesis etnohistóricas acerca del origen de los lacandones contemporáneos en notas periodísticas y panfletos.

Un segundo aspecto es la calidad de las representaciones en términos de su precisión. Aunque todas las representaciones son doblemente subjetivas; es decir, son condicionadas tanto por la subjetividad del "escritor" como por la del "lector" de una repre- 
sentación o imagen dada - la llamada doble bermenéutica-, seguimos con la necesidad de calificarlas según algún criterio. La antropología posmoderna que emergió en la década de 1980 cuestionó la autoridad etnográfica y parecía representar la inminencia de un relativismo total respecto a la calidad de las representaciones. ${ }^{6}$ A la vez, las voces del poscolonialismo ocasionaron críticas todavía más severas acerca de la práctica de la antropología, cuestionando su viabilidad como disciplina a finales del siglo xx. ${ }^{7}$ Así, la disciplina ha tenido que discutir sus raíces modernistas y sus colusiones con el colonialismo, por esto se ha visto obligada a repensar los cimientos de su visión supuestamente "privilegiada" acerca de los mundos culturales diferentes.

Pero cabe recordar que en una época donde muchos de los debates anteriormente considerados exclusivamente "antropológicos", como el carácter de la diferencia cultural, la agencia de cambio cultural, y las pugnas sobre representaciones culturales; el papel de la antropología, fundamentada en buena etnografía, resulta más importante que nunca. Al haber asumido las críticas de años recientes y haberse vuelto más sensible a los impactos políticos de las maneras en que hablamos de la diversidad cultural, su rol crítico en los debates actuales es primordial. De la misma manera que, al hacer trabajo de campo, nos preguntamos por qué un cierto individual nos cuenta una versión distinta de los "mismos" eventos comparado con otro individuo, asimismo debemos de mantener la misma postura crítica hacia las múltiples representaciones de grupos culturales que se presentan en textos, ya mediados por terceros, dentro y fuera de la disciplina.

En este quehacer, el tipo de representación también es significativo; puede ser escrita, audiograbada, fotografiada o videograbada. Casi toda representación tiene elementos de verdad: una fotografía - y menos una grabación videográfica-, por ejemplo, no puede "mentir" pero sí omitir. Igual ocurre en un texto escrito, las representaciones que tratan de una colectividad de personas siempre son el resultado de un proceso selectivo de datos —observaciones, entrevistas-, instantes — fotografías - o secuencias — videograbaciones - escogidos para construir una visión "coherente", conforme, por supuesto, con la subjetividad del autor de la representación.

\section{Cuatro dinámicas generativas}

Este artículo parte de mi propia experiencia con los lacandones de Lacanjá Chansayab y la lectura de literatura sobre ellos en libros, artículos, panfletos y notas periodísticas e imágenes producidos en otros campos. Un estudio comprensivo de los más de dos siglos de representaciones requeriría mucho más espacio del que se permite en el presente artículo. Por lo tanto, este artículo pretende brindar sólo una reseña de estas representaciones históricas para después enfocar cuatro "dinámicas generativas" que siguen influenciando las maneras de representar a este grupo humano en un rango amplio de medios y ámbitos actuales. Además, argumentaré que las mencionadas "dinámicas" constituyen un elemento importante en el desenvolvimiento de procesos políticos y sociales actuales.

La primera es, sin duda, la misma antropología. El legado de un siglo de estudios etnográficos y su influencia en la esfera pública no puede ser subestimado. La segunda dinámica es lo que denomino "política del origen". Con este término, señalo el impacto que han tenido las teorías sobre el origen de este grupo selvático sobre las maneras en que se ha representado a los lacandones en años recientes. La tercera "dinámica" es la del turismo. Con la creciente promoción de la Selva Lacandona como destino (eco)turístico, los lacandones aparecen en los materiales turísticos como si fueran el único grupo humano que radica en esta región. El turismo suele generar imágenes esencialistas de pueblos 
indígenas para alentar su "consumo" en turistas buscadores de "autenticidad" (MacCannell, 1976; Graburn, 1989). La cuarta dinámica, ligada a la anterior, es la conservación del medio ambiente. Los lacandones se han convertido en aliados clave de los conservacionistas en la coyuntura actual, e imágenes de lacandones están desplegadas por intereses conservacionistas con frecuencia.

\section{El dilema de los "ex primitivos"}

Un substrato en casi todas las representaciones de los lacandones ha sido su conexión especial, o extraordinaria, con el pasado. En los numerosos escritos acerca de los lacandones se pueden encontrar frases como "totalmente no tocados por la mano de la civilización moderna" (Caso-Mier, 1935: 10) o "no parecen ser de este mundo del siglo xx" (Margain, 1972: 65). Perera y Bruce los denominaron "Los últimos señores de Palenque" (1982) y esta conexión entre los lacandones y el patrimonio arqueológico de la región se ha enfatizado mucho más que con otros grupos indígenas en Chiapas.

Recientemente, el antropólogo Peter Hervik ha comentado que este sobreénfasis en la continuidad cultural todavía se encuentra en muchas representaciones de los mayas, tanto antropológicas como turísticas (1999: 166). Desde una postura más crítica, Fabian identificó lo que él designó "alocronismo", allochronism, en su famoso libro sobre cómo la antropología constituye su objeto de estudio (1983). Con este término, Fabian quiso señalar que mucha antropología tradicional, enfocada en el Otro "primitivo", negaba una paridad temporal a sus interlocutores en la producción de conocimiento antropológico (ibid:: 32), consignándolos a otra temporalidad.

En el ejemplo de los lacandones esta tendencia es más que evidente. Se ha destacado su pasado maya, pero tendiendo a tratar a los lacandones como fósiles 'vivos' que ofrecen pistas a un entendimiento de la época clásica; son los "sobrevivientes" de una cultura majestuosa. Aunque existe una ironía: al ser "sobrevivientes" muchos viajeros recalcaron el declive cultural de los lacandones a lo largo de los siglos, al comparar su cultura material con los restos de los centros ceremoniales dispersos en la selva. Cuando en 1882 el viajero francés Desiré Charnay pasó unas semanas en las ruinas de Yaxchilán en compañía del aficionado arqueólogo inglés Alfred Maudslay, encontró algunos incensarios lacandones en el edificio 33. Charnay afirmó que a estos objetos les faltaba "la mínima sensibilidad artística", y al comparar los incensarios con las estelas y grabados que le rodeaban en Yaxchilán, concluyó: “la diferencia de tipo es notable y tal vez indique la presencia de dos razas distintas" (Charnay, 1888: 443; traducción mía, cursivas en original). Entonces, estas representaciones de los lacandones, llevadas a cabo en referencia con su pasado maya, no caen exactamente en los estereotipos de primitivos selváticos — como tal vez en el caso de grupos indígenas amazónicos_- Más bien su cultura se entiende como una versión empobrecida de la cultura maya clásica. En el mismo tenor, Vicente de CasoMier comentó lo siguiente en su escrito titulado Among the Lacandons:

Los antepasados de estos lacandones deben haber sido hombres fuertes y altos, pero ahora se han reducido en talla de manera considerable, como se ha probado al compararlos con los datos disponibles. Ahora, son como enanos, casi como pigmeos, enfermizos, degenerados, y débiles en apariencia, pero poseen una fuerza considerable”. (1935: 12; traducción mía).

Desde luego, todas estas representaciones han dependido de las preocupaciones y preconcepciones de los que asumieron la tarea de representar a los lacandones. Por ejemplo, cuando Edwin Rockstroh, alemán radicado en Guatemala, emprendió una 
expedición "científica” por la Selva Lacandona en 1881 escribió: "¿los lacandones serían aún antropófagos?” (De Vos, 2003: 90). Al encontrar un grupo de lacandones cerca del Río Usumacinta, Rockstroh quedó decepcionado al ver que tenían entre sus pertenencias botellas, camisas de lana y un "plato de china" (ibid: 126). Terminó su viaje escribiendo que los lacandones representaban "la penumbra de la barbarie", pero que él quería ver "la sombra" (ibid: 129). Asimismo, cuando europeos como el matrimonio francés Jacques y Georgette Soustelle y la fotógrafa suiza Gertrude Duby llegaron a la selva en las décadas de 1930 y 1940, respectivamente, seguramente fueron los eventos concurrentes en Europa los que condicionaron su visión de los lacandones, en gran medida, como un pueblo no corrompido e inocente, y con poca comprensión de la propiedad privada (véase Soustelle, 1971; Duby 1944).

Los lacandones, entonces, siempre han sido sujetos a representaciones algo contradictorias. Han sido descritos, alternativamente, como salvajes, primitivos y horripilantes, en otras ocasiones "puros", "dignos", "honrados" y "sinceros", "señores de la selva". Obviamente, muchos pueblos indígenas han sufrido de las mismas imágenes contradictorias, en particular, tal vez, los habitantes de las selvas tropicales, ya que ese ambiente desconocido para los visitantes europeos siempre se ha visto de manera igualmente contradictoria en la imaginación europea; como lugares moralmente ambiguos y peligrosos pero, a la vez, edénicos (véase Slater, 1995).

Con facilidad se pueden trazar estas miradas desde las ideas europeas sobre el carácter moral de los llamados "primitivos" con la noción del "primitivo egoísta" de Hobbes, en el siglo xvII, y el "salvaje noble" descrito por Rousseau un siglo después. Pero el caso de los lacandones es distinto al de los otros pueblos indígenas de México porque estas representaciones y consecuentes debates no empezaron en el siglo XVI, sino a finales del siglo XIX, persistiendo durante el siglo pasado. Como ha comentado Paladino (1996), el "descubrimiento" de los lacandones por viajeros extranjeros en las últimas décadas del siglo xIX era parecido al "descubrimiento" de los Tasaday en las Filipinas del decenio de 1970. 'Los lacandones, en los ojos de muchos foráneos, parecían ofrecer la posibilidad de estudiar sobrevivientes mayas de la época clásica que no habían sido "contaminados" por la experiencia colonial.

Es importante mencionar que esta visión "primitiva" de los lacandones no se limita a una perspectiva "occidental" o mestiza, sino también se expresa dentro de las culturas indígenas vecinas. El ejemplo más destacado de esta visión indígena es tal vez el carnaval de Bachajón, que toma lugar anualmente en esta comunidad de habla tzeltal durante los días antes de iniciarse la Cuaresma. Este ritual indígena incluye la representación de una guerra entre bachajontecos y lacandones ocurrida en el siglo XVI, cuya consecuencia fue la reubicación del pueblo original de los bachajontecos. En esta recreación histórica vemos una representación indígena, tzeltal, de los lacandones. Mientras que los bachajontecos se presentan como cristianos y jerárquicos, con cargos bien definidos, los lacandones son seres de la naturaleza e igualitarios. Los lacandones llevan pantalones, collares de semillas y maniquíes de monos para recalcar su pertenencia a la selva tropical. La reconciliación entre los bachajontecos y los lacandones se simboliza con el intercambio de alcohol y cigarros, por caza selvática. ${ }^{10}$

Esta representación 'primitiva' de los lacandones que tienen sus vecinos indígenas, todavía expresada en el siglo Xxi, persiste en otros ámbitos, aunque sean más sutiles. Por ejemplo, el cazar y comer monos, practicado hoy por algunas familias lacandonas, es una observación que los otros grupos indígenas usan en ocasiones para distinguirse de los lacandones; es decir, los lacandones comen monos, ellos no. Asimismo, algunos vecinos 
indígenas de los lacandones han comentado que se casan con sus hermanas. En estos estereotipos de los lacandones perdura una representación como "primitivos" o "salvajes". No obstante, a la vez, se articula otro aspecto más positivo del mismo estereotipo entre los demás grupos indígenas; los lacandones vistos como "abuelos", mayas "originales" que resistieron a los conquistadores.

\section{Los lacandones en las miradas antropológicas y los peligros de la inercia etnográfica}

Casi toda la antropología versada sobre los lacandones - por lo menos hasta hace poco- puede ser caracterizada por la llamada "salvage anthropology" o "antropología de rescate". Es decir, el objetivo de muchos de los investigadores que han trabajado en comunidades lacandonas ha sido rescatar, para la posteridad, todos aquellos rasgos culturales que parecieran representar vestigios de la cultura maya prehispánica. En consecuencia, la mayoría de los estudios se han concentrado en religión, prácticas rituales, la lengua, simbolismo, parentesco, y la interacción con el medio ambiente. A lo largo del siglo xx, la visión sobre los lacandones ha sido la de un grupo humano en un estado perpetuo de desaparición, aunque, sin duda, actualmente existen más lacandones que nunca. ${ }^{11}$

Sin embargo, es curioso cómo la gran mayoría de los cálculos de su población siguen siendo subestimaciones. Por ejemplo, en el prólogo de una etnografía publicada recientemente (Boremanse, 1998), escrita por el conocido antropólogo británico Rodney Needham, se afirma que hay "algo profundamente patético en este informe, porque los Hach Winik, como portadores de las reliquias de las instituciones tradicionales mayas, son casi extintos" (1998, p. xv; traducción mía). Asimismo, un documental recientemente filmado en México sobre tres lenguas indígenas en peligro de extinción, afirma que sólo existen 104 hablantes sobrevivientes de la lengua maya lacandón (Serra, 2003). Incluso el periódico L a Jornada, que a menudo comenta sobrela situación actual en la Selva Lacandona, ha descrito a los lacandones como "un pequeño pueblo maya en vías de extinción” (10/5/02) y "con menos de 200 miembros sobrevivientes" (18/3/02).

Seguramente, debido a sus números limitados y la promesa de ofrecer pistas sobre las prácticas prehispánicas, los lacandones tienen el "privilegio" de haber sido de los primeros grupos indígenas en México que inspiró un estudio etnográfico por parte de un antropólogo "profesional". Entre 1902 y 1905, el etnólogo norteamericano Alfred M. Tozzer llevó a cabo cuatro temporadas de trabajo de campo entre los lacandones, publicando un estudio comparativo en 1907 titulado "Mayas y lacandones: Un estudio comparativo" — la versión en español vio la luz en 1982_. Por aquel entonces, todavía existían rumores —divulgados en parte por los libros de John Stephens (1841 y 1843) que en el siglo XIX aún existía una ciudad maya en las selvas de Chiapas y Guatemala donde la gente vivía como en la época clásica. El descubrimiento en 1882 por Charnay y Maudslay de actividad religiosa por parte de los lacandones en las ruinas de Yaxchilán, al lado del río Usumacinta, fue uno de los acontecimientos que intrigó a 'Tozzer y le impulsó a iniciar sus investigaciones de campo. De cierta manera, Tozzer encontró lo que buscaba. En 1905, ya terminando su último viaje a Chiapas, escribió en uno de sus informes:

Cada vez estoy más y más impresionado por las múltiples y sorprendentes supervivencias de la antigua cultura maya según la describieron los primeros cronistas. Estas supervivencias están muy lejos de ser casuales y apenas existe un punto de complicado ritual que ahora practican los lacandones que no se encuentre su contraparte en los ritos y costumbres que fueron descritos en el tiempo de la conquista (Tozzer, 1905, citado en Villa Rojas, 1982: 9) 
Esta representación de los lacandones - como puente etnográfico al pasado prehispánico- ha dominado la mayoría de los estudios antropológicos desde el estudio pionero de Tozzer. ${ }^{12}$ Con el descubrimiento de Bonampak en 1946, los lacandones llegaron a ser vistos, literalmente, como "estelas caminantes". ${ }^{13}$ Así escribió el arqueólogo Carlos Margain en 1951:

[...] vemos que los personajes representados en los relieves, tan riquísimamente ataviados, son positivos retratos de los lacandones. El parecido es tan enorme que nuestros ojos resisten a creer lo que ven: relieves que caminan, que nos hablan, a los que podemos tocar. [...] ¿Y quiénes son estas gentes? Que son descendientes de los pintores de Bonampak es indudable: su parecido físico los hace ver verdaderos $i d o l o s$ vivientes y la lengua que hablan - un maya arcaico, comparado con el actual- nos lo atestigua de inmediato (1972: 32). ${ }^{14}$

Esta visión arqueológica de los lacandones sigue hasta hoy, y ha sido retomada tanto por los mismos lacandones como por otros. Por ejemplo, en el año 1999 se echó a andar una iniciativa en Lacanjá Chansayab impulsada por un grupo de jóvenes lacandones - El Grupo para el Rescate de la Cultura Lacandona-, que pretendía escenificar la historia representada en los murales de Bonampak, sitio arqueológico ubicado a unos diez kilómetros de Lacanjá Chansayab. El éxito de este proyecto local fue limitado, aunque la idea esencial fue retomada por una compañía privada llamada Maya Performance en 2002, quien puso en escena un espectáculo llamado "El Señor de la Tierra" al año siguiente. En esta obra de teatro "multimedia", jóvenes actores lacandones, entre otros, representan la historia de los mayas pintada en los famosos murales de Bonampak del siglo VIII. ${ }^{15}$

Otros antropólogos siguieron a Tozzer, como los Soustelle en la década de 1930 y, luego, en 1943, el arqueólogo danés Frans Blom con su futura esposa Gertrude Duby, quienes asistieron a una expedición gubernamental a la Selva Lacandona en donde su encuentro con los lacandones llegó a marcar el principio de una larga relación entre esta pareja extranjera y el pequeño grupo (Duby, 1944; Blom y Duby, 1955 y 1957). El establecimiento, en 1951, de la Asociación Cultural Na-Bolom en San Cristóbal de Las Casas cimentó esta vinculación, hasta el día de hoy les siguen apoyando. La relación con Gertrude Duby, quien dedicó más y más tiempo a cuestiones ambientales y a la preservación de los lacandones y la selva, es quizá mejor representada por las famosas fotografías que ella tomó de sus amigos lacandones por más de 40 años. ${ }^{16}$

El interés etnográfico en los lacandones alcanzó su auge entre 1960 y 1970, cuando antropólogo tras antropólogo llegaba a Nahá para trabajar con el mismo informante clave, Chank'in Viejo. ${ }^{17}$ Sin duda, las investigaciones realizadas en esta época tienen su valor, pero ignoran casi por completo la situación política de las comunidades lacandonas después de la creación de la Comunidad Lacandona en 1972 y su relación subsiguiente con el gobierno federal. La imagen primordial es la de un mundo a punto de esfumarse debido a la ignorancia y avaricia del mundo exterior.

Por un lado, este legado antropológico ofrece ricas posibilidades de poner trabajos contemporáneos en perspectiva histórica, por otro, resulta problemático. Debido a la influencia que ha tenido la antropología en las representaciones de los lacandones, de manera directa e indirecta, es posible identificar lo que designo inercia etnográfica. Con este término quiero identificar varios procesos. En primer lugar, la cantidad de material etnográfico disponible y su enfoque de rescate da una impresión muy sincrónica de los lacandones. Los peligros del presente etnográfico combinados con los acelerados cambios experimentados por las comunidades lacandonas en los últimos treinta años significan que las etnografías “caducan” rápidamente. 
De nuevo, esto no es un problema único al caso lacandón. Las etnografías inevitablemente se vuelven etnohistorias con el paso del tiempo. El peligro se encuentra cuando se leen estas etnografías como si representaran una realidad actual. Bastan dos ejemplos para demostrar este fenómeno en los lacandones.

En 1980, los antropólogos James Nations y Ronald Nigh publicaron un artículo sobre el manejo de las milpas y acahuales lacandones, destacando la diversidad, rendimiento y sustentabilidad de este sistema agrícola de tumba, roza y quema. Fue el primer estudio agrónomo y etnobotánico de las prácticas lacandonas y, sin duda, tenía un valor importante en el momento de publicarlo, todavía tiene valor más bien como estudio ya de carácter histórico. El problema es que se sigue citando con regularidad este artículo en varias fuentes para fundamentar una visión de la agricultura lacandona como una práctica innatamente conservacionista, dando la impresión de que la mayoría de los lacandones siguen manejando sus milpas en la manera descrita por Nations y Nigh hace 25 años. Actualmente en Lacanjá Chansayab, donde la investigación para aquel artículo fue llevada a cabo, existen 144 jefes de familia. Con base en mi propio trabajo de campo considero que menos de cinco de éstos siguen manejando sus milpas y acahuales en la manera "tradicional" descrita por Nations y Nigh, y ninguno mantiene el nivel de diversidad que ellos dan a entender en su artículo. ${ }^{18} \mathrm{Sin}$ embargo, el artículo está citado en el Programa de Manejo para la Reserva de la Biosfera Montes Azules (INE-SEMARNAP, 2000) como evidencia de la sustentabilidad inherente de la milpa lacandona. Además, en un documento elaborado por Conservación Internacional México, A. C., llamado "Estrategia Conjunta para la Conservación de la Biodiversidad", se recomienda que el sistema de la milpa lacandona sea rescatado para ser utilizado "como un modelo para la agricultura sustentable en la región". ${ }^{19}$
Un segundo ejemplo del efecto de esta "inercia etnográfica" sobre las maneras en que se ha representado a los lacandones, se encuentra en un artículo que se publicó en 2000 titulado "Bajo la sombra de la gran ceiba: la cosmovisión de los lacandones", escrito por Marie-Odile Marion. De nuevo, mi propósito no es el de criticar el artículo, que ofrece un resumen bien escrito de la "cosmovisión" histórica de los lacandones. Pero, al formar parte de una colección que protesta proporcionar al público "una idea más acabada de la concepción cosmogónica que hoy sustentan los diversos grupos étnicos de nuestro país" (Desacatos, 2000: 11; cursivas mías), el artículo resulta algo engañoso. Uno se pregunta cuántas personas lacandonas serían capaces de articular la cosmovisión lacandona que Marion describe como "una cosmovisión nativa maya contemporánea, arraigada en antiguas formas de pensamiento cuya función es reproducir la identidad cultural del grupo" (Marion, 2000: 45; cursivas mías). En Lacanjá Chansayab, comunidad que conozco mejor y donde vive la mayoría de los lacandones actuales, dudo que exista un individuo que pueda expresar su "cosmovisión" de la manera cómo lo hace esta autora. Desde luego, no se sabe qué influencia ha llegado a tener esta representación de los lacandones, pero en mi opinión, representa los peligros de mostrar material etnohistórico como si fuera etnografía actual, y puede llegar a sostener una imagen de los lacandones que resulta imprecisa, anacrónica y descontextualizada, que desemboca en el romanticismo. ${ }^{20}$

\section{La política de origen: ¿lacandón, caribe o hach winik?}

El debate acerca del origen de los lacandones actuales solía ser un asunto exclusivo de etnohistoriadores y antropólogos, pero con el decreto que creó la Comunidad "Zona Lacandona" en 1972, mediante la lógica de una restitución y con la creciente 
politización de la situación agraria en la selva, se ha vuelto un tema muy discutido. Basándose en teorías que mantienen que los antepasados de los lacandones actuales llegaron a la selva a finales del siglo XVIII, un grupo que había sido retratado como autóctono a la región llegó a ser representado como el beneficiario no mereciente de un acto agrario debido a su "recién" llegada al lugar. ${ }^{21}$ Una anécdota de campo tal vez sirva para ilustrar este fenómeno.

En 2002, un hombre que trabajaba para una empresa de Tenosique, Tabasco, y compraba palma xate o camedor, a la Comunidad Lacandona para luego venderla en el mercado internacional, fue detenido en una comunidad a unos 40 kilómetros de Lacanjá Chansayab. Un joven lacandón —a quien llamaremos "Pedro" - también trabajador de la misma empresa, llegó a este poblado para intentar resolver el problema relacionado con una supuesta deuda que la empresa tenía con miembros de esta comunidad cortadores de palma. Pedro fue recibido por los que él describió como zapatistas —esta comunidad se encuentra dentro de uno de los municipios autónomos-. Al darse cuenta que Pedro era lacandón, los de la comunidad le gritaban "ipinche caribe!” y sacaron un artículo de un periódico con una fotografía de un lacandón que tenía un puesto en las autoridades comunales de aquel entonces. Este hombre lacandón, mantenían los "zapatistas", había acusado a su comunidad de ser asaltantes. Esto no era cierto, ellos protestaban, y procedieron a sacar una fotocopia de un libro que, según ellos, probaba que los lacandones no eran originarios de Chiapas, sino de Campeche, y por lo tanto, siendo "caribes", no tenían ningún derecho a la tierra de la Selva Lacandona, ni a vender sus recursos naturales —en este caso, la palma xate.

Esta anécdota ilustra cómo los debates académicos pueden impactar en las relaciones étnicas de manera muy directa. El uso de la palabra "caribe" para describir a los lacandones implícitamente cuestionaba su origen y se empleó de manera despectiva. Obviamente, el uso de dicha palabra para describir a los lacandones contemporáneos es inapropiado, porque este grupo maya no tiene nada que ver con los indígenas caribes que provenían de las costas de Venezuela antes de la época colonial y dieron nombre al mar conocido como tal. Sin embargo, el término fue usado durante la época colonial para designar "todo tipo de indio insumiso, bárbaro, infiel, montaraz, idólatra, antropófago, etcétera" (De Vos, 1980: 214).

¿Qué importancia tiene un nombre? El nombre por el cual un grupo de gente es conocido constituye elemento fundamental en su representación, sea por sí mismo o por otros. Desde la perspectiva de los propios lacandones, ni el término "lacandón" ni la palabra "caribe" tienen mucho sentido como términos de autorreferencia. Para los lacandones, la palabra 'lacandón' — o su raíz "lacan tun"-, no tiene significado en su lengua: "can" quiere decir serpiente, y “tun”, piedra; pero 'lacandón' no quiere decir nada en maya lacandón. Ellos se llaman a sí mismos "bach winik", gente verdadera, o simplemente "winik", gente; y, para indicar en conversación que alguien es lacandón, "ik boho'b", nuestro compañero. ${ }^{22}$ La palabra 'lacandón' es de origen choltí, y es una corrupción de la palabra lacan tun, — $\mathrm{O}$ akan tun con el artículo español añadido-, quiere decir "piedra grande" o "piedra parada". Es más bien un referente geográfico que denominaba la isla rocosa de la Laguna Miramar. La población choltí que habitaba esta isla hasta 1586 recibió el nombre de los españoles: los lacandones actuales lo heredaron.

El origen de los lacandones ha sido muy debatido, ${ }^{23}$ parece que en el contexto de Chiapas y México los trabajos de Jan de Vos $(1980,1995)$ han tenido la última palabra acerca de este asunto. Se mantiene que los lacandones actuales son los descendientes de mayas de habla yucateca que se refugiaron en la región 
guatemalteca ahora conocida como El Petén durante la época colonial. Según De Vos, la primera evidencia en las fuentes que indica que estos lacandones, o "caribes", habían cruzado el río Usumacinta para asentarse en lo que ahora conocemos como la Selva Lacandona es en 1697, cuando una comunidad "caribe" fue localizada en un paraje llamado Yucum, a ocho días de camino de El Palenque (De Vos, 1980: 220). Por lo tanto, los lacandones actuales llevarían por lo menos 300 años radicando en Chiapas.

Este debate etnohistórico es relevante a la presente discusión porque en los últimos años el "origen" de los lacandones fuera de Chiapas se ha usado para desacreditar su posición agraria ${ }^{24} \mathrm{y}$ hasta cuestionar su "autenticidad" como mayas en algunos casos. De Vos mismo empezó este cuestionamiento en su primer volumen acerca de la historia de la Selva Lacandona, Lapaz de Diosy del Rey. El autor concluye:

[...] no se puede por consecuencia considerar a estos caribes o lacandones como los pobladores originales ni a sus descendientes como los dueños legítimos de la Selva Lacandona (1980: 231).

De Vos termina su libro con un comentario más sobre los respectivos derechos de los pobladores actuales de la Selva Lacandona:

Los que han creado, entre los años 600 y 900 d.C., el "milagro maya" en la Selva Lacandona fueron probablemente los antepasados de los lacandones [es decir, los lacandones choltís], que se extinguieron en el siglo XVIII, y de las comunidades choles y tzeltales que en el siglo XVI fueron sacadas de la selva por Fray Pedro Lorenzo y cuyos descendientes están ahora regresando a esa misma selva en búsqueda de nuevas tierras. Si existe algún título histórico de propiedad sobre la selva de Chiapas lo poseen los colonos tzeltales y choles que viven ahora en más de doscientas colonias esparcidas en la Selva Lacandona (1980: 247-248).
Las investigaciones de Jan de Vos han sido retomadas por varios actores para apoyar un discurso que trata de deslegitimar a los lacandones en la coyuntura actual, especialmente con referencia en las "invasiones" de la Comunidad Lacandona por parte de poblaciones indígenas desde el levantamiento zapatista en 1994. Por ejemplo, en un panfleto escrito por la Asociación Civil Maderas del Pueblo del Sureste titulado "Breve Historia de la llamada 'Comunidad Lacandona' — o cómo los caribes se sacaron la lotería sin comprar billete...-" (2002), podemos observar cómo estos debates etnohistóricos pueden ser aplicados a situaciones actuales. En este documento, que se apoya en gran parte en los textos de Jan de Vos, los lacandones actuales son "indios caribes", y los lacandones antiguos —es decir, los habitantes de la isla Lacam-tún en el siglo XVI- son los "lacandones verdaderos, dueños y habitantes ancestrales de la selva" (2002: 3). Además, los últimos son retratados como "rebeldes y guerreros que resisten ataques armados de los conquistadores españoles defendiendo su territorio" (2002: 1), a diferencia de los "caribes", quienes eran "pacíficos" y venían de Campeche. Al referirse al decreto que otorgó las famosas 614321 hectáreas a los lacandones en 1972, el panfleto dice lo siguiente:

\footnotetext{
Los caribes nunca pudieron mostrar títulos primordiales ni restos de poblados que demostraron que ellos eran los dueños y habitantes ancestrales de todo el gran territorio que el gobierno les regaló. Y no podían demostrarlo porque los antepasados de los caribes no nacieron ahí, sino llegaron a colonizar la Selva Lacandona desde Campeche [...] Entonces, los caribes también eran colonos e "irregulares" (2002: 10). ${ }^{25}$
}

Este discurso exige varios comentarios. En primer lugar, la comparación entre los dos grupos de "lacandones" es cuestionable. Los lacandones actuales están representados como los herederos no dignos de un nombre que originalmente designaba a una isla, no 
a una población humana; ninguno de los dos grupos —ni los lacandones antiguos ni los actuales — usaban el término "lacandón" para describirse a sí mismos. En segundo lugar, describir a los lacandones antiguos como los "dueños y habitantes ancestrales de la selva" y a los actuales como "irregulares" es asumir la existencia de un "año cero", un tiempo ficticio cuando todas las poblaciones humanas del planeta radicaban en su lugar de origen, a lo cual tenían derechos ancestrales de propiedad. En el contexto de México este "año cero" tiende a ser el momento de la conquista española, es decir, en la Selva Lacandona sería el año 1525.

Las variadas interpretaciones de la historia poscolonial en México generalmente ponen énfasis en la Conquista como el evento clave para determinar "lo indígena" como una categoría cultural contemporánea. En este ejemplo, la tendencia queda clara; los lacandones antiguos tienen derecho ancestral a la Selva Lacandona — porque radicaban allí cuando llegaron los españoles - , pero los lacandones actuales no tienen dicho derecho porque se supone que llegaron a la región - hay que recordar, de otra parte de la Nueva España_ “sólo” hace aproximadamente 300 años. En otras palabras, la fecha 1525 se presenta como el momento clave para determinar los derechos ancestrales. Desde luego, lo que está en juego aquí es el concepto del derecho histórico a la propiedad tal como está definido por el Estado, pero el propósito del presente artículo no es el de entrar en esta discusión compleja. Más bien, lo que quiero destacar es el carácter contradictorio del argumento en cuestión y el efecto que ha tenido sobre cómo los lacandones han llegado a ser representados en algunos espacios. En el contexto de este argumento, los lacandones actuales son presentados como "impostores" que "robaron" el nombre de sus antecesores y representan un grupo totalmente distinto de los moradores "originales" de la Selva debido a que la lengua que hablan está relacionada con el maya yucateco.
Como nos recuerda Richard Wilk (1999) en un artículo que retoma un conflicto de derechos históricos bastante parecido al de la Selva Lacandona pero en el contexto de Belice, incluso un conocimiento etnohistórico "perfecto" de la región no puede, necesariamente, resolver reclamos históricos. El concepto de derecho histórico es, nos dice Wilk, un concepto moderno, y las "culturas" no son entidades herméticas, como especies distintas o unidades taxonómicas, sino cambiantes y mezcladas. El problema con el caso en cuestión es que debido a una definición de cultura bastante limitada - los lacandones son de habla yucateca, por lo tanto son yucatecos-y una dependencia en un argumento etnohistórico que queda por resolverse - hay que recordar que no existe un consenso entre los varios etnohistoriadores que han investigado la historia de los lacandones en el siglo XVII y XVIII - , los lacandones son descalificados. ${ }^{26}$

\section{Vendiendo la selva, salvando la selva: los lacandones en la mirada turística y ambiental}

Las últimas dos "dinámicas" que han jugado un papel significante en la representación de los lacandones en los últimos años son el turismo y el ambientalismo. Los trato juntos porque se traslapan de muchas maneras, y los esencialismos que producen sobre este grupo selvático tienen mucho en común, simbolizado de manera clara en el llamado "ecoturismo", tan promovido últimamente en la región por diversas agencias. Muchos comentadores han enfatizado el papel del turismo en la producción y el mantenimiento de imágenes esencialistas de pueblos indígenas (por ejemplo, Hervik, 1999). De igual forma, mucho se ha comentado sobre las imágenes esencialistas generadas acerca de los pueblos autóctonos por el discurso ambientalista (Brosius, 1999: 280). Según Conklin y Graham, escribiendo en el contexto de la Amazona, los pueblos indígenas poseen "capital 
simbólico" y "las ideas positivas acerca de los indios y sus relaciones con la naturaleza se han convertido en un recurso simbólico potente en las políticas trasnacionales" (1995: 696, traducción mía).

En el caso del turismo, es importante reconocer que este sector va más allá de su promoción y la experiencia del turista visitante; también afecta el "turisteado", o sea, la persona o comunidad que recibe a los turistas. En algunos casos, el turismo puede dirigir a un proceso en el cual la identidad o etnicidad del "turisteado" esté reforzada (ver Van den Berghe y Keyes, 1984; Greenwood, 1989). Sin duda, este proceso se ha dado en los lacandones de Lacanjá Chansayab. El interés explícito en los lacandones y en su "cultura" por parte de fuereños visitantes ha afectado la autoimagen de muchos lacandones, alentando una revalorización de su identidad, única como grupo étnico. Pero, a la vez, es importante enfatizar que en este encuentro entre turistas y "nativos", el concepto de "cultura" manejado por ambas partes tiende a reducirse a una noción donde la "cultura" es nada más una colección de destrezas, rasgos y productos artesanales, percibida como a punto de desvanecerse.

Además, y como hemos discutido en otros espacios (Trench, 2002; Köhler y Trench, 2004), al hablar del "impacto" turístico en las representaciones de un grupo étnico, es importante reconocer la dificultad de aislar el efecto del turismo de otras prácticas y otros discursos que también inciden en estas representaciones. Resulta claro que en las últimas décadas la presencia de grupos indígenas "tradicionales" en el territorio nacional se ha convertido en un recurso turístico y un "bien" cultural para México (Friedlander, 1986). No es sorpresa, entonces, que en el paisaje turístico del recreado Mundo Maya los lacandones figuren de manera importante debido a su apariencia “exótica", su ubicación en una selva tropical y su status - contradictorio- como descendientes directos de la época clásica maya por un lado, y "ex primitivos" por el otro.
Entonces, los esencialismos e imágenes de autenticidad mítica reproducidos en el campo del turismo muchas veces no son exclusivos de la actividad. En el contexto chiapaneco vemos que imágenes de los lacandones, con sus túnicas tradicionales y casi siempre en el ambiente selvático — es decir, no en sus casasaparecen tanto en la publicidad estatal trasmitida por el Canal 10 —del Estado- como en materiales que promueven el turismo en la entidad y la Selva Lacandona. Los lacandones se han convertido en un "logotipo" para la selva y el estado de Chiapas. Este "logotipo" sirve tanto para atraer el turismo como para reforzar una imagen única en la entidad y sus pueblos originarios. Por ejemplo, un póster producido por la Secretaría de Turismo, SECTUR, que adorna las paredes de muchas agencias de viajes en Chiapas, muestra a un hombre lacandón sentado enfrente del Palacio en el sitio arqueológico de Palenque. Cabe mencionar que la comunidad lacandona más cercana a Palenque está a casi cien kilómetros, y que el sitio arqueológico de Palenque está rodeado por comunidades indígenas choles. Pero queda claro que los miembros de estas comunidades indígenas no sirven a la mercadotecnia turística, pues no se visten "como indígenas", por tanto no proveen la "autenticidad" $\tan$ buscada por los promotores del turismo.

Los traslapes entre turismo y ambientalismo están muy claros en el caso de los lacandones. Por ejemplo, en la comunidad de Lacanjá Chansayab han sido las autoridades ambientales - Instituto Nacional de Ecología, INE, y la Comisión Nacional de Áreas Naturales Protegidas, CONANP— las que han jugado un papel clave en la promoción de esta actividad entre los lacandones. En 2000, fue el INE quien impulsó el proyecto ecoturístico en el área protegida del Monumento Natural de Bonampak, construyendo el Centro de Interpretación Ambiental y Servicios, a la entrada del camino que dirige al sitio arqueológico de Bonampak. En el espacio museográfico de este Centro, 
los visitantes pueden informarse sobre las relaciones "tradicionales" entre los lacandones y su medio ambiente. También el INE erigió letreros turísticos en 2001, señalando dónde encontrar "milpas tradicionales lacandonas" en la comunidad. Además la infraestructura turística en Lacanjá Chansayab ha recibido el apoyo de varias agencias como Conservation International, la asociación civil Espacios Naturales y Desarrollo Sustentable, y Ford Motor Company, que han apoyado el desarrollo del "ecoturismo" en esta comunidad en el nombre de la conservación de la selva. ${ }^{27}$ Las paredes de las oficinas federales de la CONANP, Tuxtla Gutiérrez, están adornadas con fotografías de lacandones en su “ambiente natural". En cambio, los otros habitantes de la selva, indígenas tzeltales, choles, tojolabales, tzotziles y mestizos de diversos orígenes, no tienden a figurar en esta representación "pintoresca" de los moradores selváticos.

Esta imagen de los lacandones como "conservacionistas naturales" no sólo ha permanecido a un nivel discursivo. Como ya se ha mencionado, la "milpa tradicional" de los lacandones sigue recibiendo la atención de los investigadores científicos y se ha convertido en una atracción turística en Lacanjá Chansayab. En el plan de manejo de la Reserva de la Biosfera Montes Azules, el área protegida más antigua y más grande de la Selva Lacandona, se concedió a los lacandones una "zona de uso tradicional". Este perímetro, de casi 4000 hectáreas, se destina —en teoría - al rescate activo de los conocimientos lacandones respecto a la gestión de los recursos naturales, a través de la investigación etnobotánica (INESEMARNAP, 2000).

La mencionada imagen de los lacandones ha sido reforzada últimamente con el lanzamiento en 2003 de una campaña llamada “'Que Viva la Selva Lacandona!” Campaña apoyada por Ford Motor Company y Fundación Azteca; difundida a través de TV Azteca pretendía concienciar al público mexicano sobre la problemática del deterioro ambiental en la selva chiapaneca. Los lacandones fueron clave en estos reportajes y en la promoción de la campaña, jugando el papel característico de "buenos indios" y "ambientalistas naturales". Un grupo de lacandones, los hombres vestidos con túnicas blancas, apareció en cuatro ocasiones en los estudios de TV Azteca, entre agosto y septiembre de $2003 .{ }^{28}$ La campaña invitaba a niños de la república a mandar dibujos de la selva para ganarse un viaje a Lacanjá Chansayab y "conocer este lugar exótico". Los lacandones fueron descritos, por Pablo Latapí, como gente "luchando todos los días para salvar a la Selva Lacandona". Además, se destacaba la criminalidad de los grupos "invasores" — por cierto, también indígenas mayas - que habían ocupado tierras dentro de la Reserva de la Biosfera Montes Azules, subrayando la batalla que enfrentan los lacandones para salvar "su" selva.

Como ya se ha comentado, el problema de esta imagen de los lacandones no es tanto sin fundamento; la relación histórica que los lacandones mantenían con el ambiente selvático era distinta a la de los otros grupos indígenas que colonizaron la región. El problema más bien radica en que esta representación resulta ser poco precisa en la actualidad, dado que la economía de Lacanjá Chansayab cada vez es menos dependiente de la agricultura y la recolección, debido a las oportunidades presentadas por el turismo, el trabajo asalariado y proyectos gubernamentales de "desarrollo". Además, la imagen de los lacandones como el "único" grupo capaz de vivir en armonía con la selva desvaloriza implícitamente las prácticas, experiencias e innovaciones de otros grupos indígenas y no indígenas que viven también ahí. ${ }^{29}$

\section{Autoimágenes}

Por razones obvias, los lacandones no se han interesado, todavía, en elaborar y difundir una representación 
"contra-hegemónica" de ellos mismos. Es decir, no se encuentran aprovechando los nuevos medios de comunicación para poder participar en la creación de imágenes — audiovisuales — de su propia gente según una "sensibilidad" exclusivamente lacandona. ${ }^{30}$ Esto presenta un contraste con algunos otros grupos indígenas, que se han apropiado de las nuevas tecnologías para elaborar representaciones alternativas acerca de ellos mismos (véase, por ejemplo, Turner, 1991).

No quiere decir que los lacandones están totalmente ausentes de los espacios donde pueden afectar el carácter de sus representaciones. Su frecuente contacto con los visitantes - turistas, investigadores, periodistas, funcionarios, políticos, etc. - y su relativo peso político como miembros de una comunidad agraria - la Comunidad Lacandona - con un perfil institucional en una región altamente estratégica — la Selva Lacandona-, significa que pueden incidir en cierta medida en su representación pública. De hecho, resalta que muchos individuos lacandones están más que acostumbrados a ver imágenes visuales de ellos mismos, en fotografías y reportajes televisivos mostrados en el ámbito estatal y nacional.

También llama la atención el uso estratégico de la túnica por parte de los hombres lacandones con, por ejemplo, la visita del gobernador o el presidente de la República a la comunidad, o para una reunión importante o una entrevista filmada. Aunque es una minoría la habituada a vestir con túnica, la mayoría tiene al menos una prenda de este tipo para tales ocasiones. Como respondió un hombre al ser preguntado si sentía orgullo de ser lacandón:

Sí, porque nunca me voy a cortar el pelo, ni voy a dejar mis costumbres. Nunca me voy a sacar la túnica [...] Hay gente que llega, como el gobernador o el presidente, y que me invitan, si me cortara el cabello no van a saber que soy lacandón o me pueden confundir como miembro de otra comunidad. ${ }^{31}$
La túnica, entonces, como sinécdoque de su identidad diferenciada es un recurso importante en el "ser" lacandón. Representa, desde luego, el despliegue de un "esencialismo estratégico", la proyección consciente de una imagen de ellos mismos que resulta altamente efectiva en diversos espacios.

\section{Conclusiones}

La fascinación que los lacandones siguen ejerciendo en ciertos ámbitos — la antropología, el turismo y el ambientalismo_ y las representaciones icónicas que se han producido responde, a fin de cuentas, a un aspecto innegable de la modernidad misma. Como escribió Dean MacCannell hace casi treinta años en su estudio pionero sobre el turismo, "la mejor indicación de la victoria final de la modernidad sobre otros arreglos socio-culturales no es la desaparición del mundo no moderno, sino su preservación y reconstrucción artificial en la sociedad moderna" (1976: 8, traducción mía). Representaciones de los lacandones, con sus túnicas, sus arcos y flechas, y su conocimiento "tradicional", traen ventajas inmediatas en la coyuntura actual. Pero cuando la inversión gubernamental en la infraestructura turística en Lacanjá Chansayab supera con mucho la que se dedica a educación, salud y vivienda, uno debe de cuestionar el impacto de estas imágenes anacrónicas.

El problema con las imágenes de los lacandones discutidas en este artículo ha sido, previsiblemente, sus imprecisiones, sus parcialidades y su efecto en otros ámbitos, como por ejemplo, la política ambiental en la Selva Lacandona. Pero, al fin y al cabo, volvemos a la pregunta expresada al principio de este artículo: ¿cómo describir a los lacandones como un grupo humano distinto sin caer en estereotipos, exotismo y etnocentrismo? Esto es, por supuesto, la tarea idónea de la antropología. Una respuesta fácil sería la de exigir más "objetividad" y rigor en la descripción etnográfica, pero el caso de los lacandones es indicativo de una 
tendencia cada vez más común. La antropología contemporánea — y sus practicantes — se encuentra batallando en contra de fantasmas de su propia creación; es decir, los lacandones, como los hemos llegado a conocer, son en ciertos sentidos un producto de la antropología misma.

Desde un principio, entonces, es esencial reconocer que la antropología — sus prácticas, discursos y textosya no existe fuera de las propias concepciones de sus "objetos" de estudio. Por lo tanto, la antropología impacta no sólo en las representaciones más amplias de un grupo de gente considerado de compartir una misma cultura, sino también puede llegar a saturar las propias nociones de esta gente sobre sí misma. Mientras que en el pasado los portadores de una cultura vivían poco conscientes de su "cultura" — o de la cultura de cualquier otro grupo-, actualmente su experiencia vivida tiende a ser enmarcada y constituida por la noción de "cultura" (Castañeda, 1996: 17). En el caso del que hablamos, este proceso se hace evidente de dos maneras. Aunque no ha llegado el punto donde los lacandones respondan a los interrogatorios de una nueva generación de investigadores leyendo una etnografía previa acerca de ellos mismos, su discurso "culturalista" revela muchos años de contacto con foráneos fascinados por este tema. Muchos miembros han asumido su "excepcionalidad etnográfica", y ven su utilidad tanto en los ámbitos del turismo y ambientalismo como en sus luchas territoriales actuales. Aun así, actualmente, es el antropólogo o el turista informado quien, en ocasiones, se encuentra "explicando" la cultura lacandona a una generación de jóvenes lacandones que ya no se interesan mucho por las costumbres de sus abuelos.

Sin embargo, el tema lacandón nos demuestra que los antropólogos - y etnohistoriadores — no pueden esperar producir textos sólo para el "consumo interno". Por ejemplo, he visto turistas que han llegado a Lacanjá Chansayab con etnografías en sus mochilas, específicamente los trabajos de Robert Bruce (1982) y Marie-Odile Marion (1991, 1997). Además, como hemos mencionado, relecturas de ciertos estudios etnohistóricos que tratan la región han incidido en el debate público sobre los derechos respectivos de los moradores actuales de la selva. Por un lado, está bien que nuestros esfuerzos se encuentren en el dominio público. Pero, por otro lado, quizá resulte importante enfatizar la caducidad de nuestros trabajos etnográficos - como investigaciones realizadas en un determinado periodo-, y la provisionalidad de los estudios etnohistóricos -basados en documentos que han sobrevivido hasta nuestra época-. Afirmar esto parece devaluar el trabajo académico que hacemos, más bien es un llamado a una participación más manifiesta en los debates actuales por parte de los estudiosos.

Otro aspecto llamativo es que no representa simplemente el caso típico de la romantización de una minoría étnica selvática, sino que aquí también se ha dado una reacción en contra de esta idealización previa. Los lacandones, como sujetos, ahora se encuentran entre dos imágenes igualmente extremas e imprecisas. Ni la imagen romántica de los lacandones como conservacionistas "naturales", ni su retrato como pueblo ya alejado del medio selvático es de mucha ayuda en la coyuntura actual de la selva. Pero estas representaciones desmedidas indican la emergencia de una "eco-jerarquía" en la Selva Lacandona, donde se culpan unos a otros, a veces basados en información de calidad dudosa. Precisamente en este debate los antropólogos deben de incurrir, aportando argumentos fundamentados en la etnografía y alentando una sensibilidad entre todos los actores involucrados -incluyendo, por supuesto, a los lacandones - acerca de los peligros de estas representaciones recargadas y sus impactos en la coyuntura actual de la Selva Lacandona. Se espera que este artículo represente una modesta contribución a esta tarea pendiente. 


\section{Notas}

${ }^{1}$ La primera fotografía conocida de un grupo de lacandones fue tomada por Desiré Charnay en 1882 (véase Charnay, 1888). El primer registro de cinematógrafo conocido referente al grupo fue filmado por Frans Blom y Oliver Farge en 1925, durante su primera expedición a la región patrocinada por la Universidad de Tulane, Louisiana, E.U. (véase Blom y Farge, 1926 y 1927). Las partes relacionadas con los lacandones están disponibles en el CD-Rom "Memoria Lacandona" (NaBolom/ECOSUR, 2001).

${ }^{2}$ Recientes videodocumentales incluyen Ortela, 2001, Chank'in Najbor et al., 2001 y Serra, 2003.

${ }^{3}$ http://www.geocities.com/RainForest/3134/.

${ }^{4}$ Existe bastante evidencia de que los contactos entre los lacandones y la población mestiza (principalmente chicleros y monteros) en la primera mitad del siglo xx fueron violentos en ocasiones (véase Blom y Duby, 1955; Baer y Merrifield, 1972). Además, los lacandones asentados en la franja occidental de la selva (p.ej. San Quintín, Monte Líbano, El Censo, Nahá y Metsabok) empezaron a tener pugnas con los colonizadores indígenas que habían entrado en la selva a partir de la década de 1950 en busca de tierras, obligándolos a adentrarse más en la selva.

${ }^{5}$ En 2003, se conformó el llamado Grupo de Trabajo para la Atención Integral de la Comunidad Lacandona y la Reserva de la Biosfera de Montes Azules, una entidad intersecretarial encabezada por la Secretaría de la Reforma Agraria, SRA, que se encuentra en el proceso de regularizar la tenencia de la tierra en la CZL y la Reserva de la Biosfera. Es obvio que este proceso gubernamental ha producido diversos conflictos sociales y mucho debate en diversos medios de comunicación, en particular respecto a los derechos y orígenes de los lacandones.

${ }^{6}$ Véase especialmente Rorty, 1980; Clifford y Marcus, 1986; Clifford, 1988.

${ }^{7}$ Véase, en particular, Said, 1978, y Fabian, 1983. Cabe notar que esta crítica se dio más dentro de la antropología euroamericana, enfocada en la exoticización de los anteriores sujetos del colonialismo europeo. En México, este debate se ha dado de manera distinta.

${ }^{8}$ Véase, por ejemplo, Maler, 1903; Caso-Mier, 1935; Duby, 1944; Amram, 1947; Blom y Duby, 1955; Pina Chan, 1961; Ivanoff, 1967; y Margain, 1972.

${ }^{9}$ Los Tasaday fueron un grupo indígena de las selvas de Filipinas que fueron "descubiertos" en 1971. Como este pequeño grupo de 26 individuos parecía ser superviviente de la edad de piedra (vivían en cuevas y usaban únicamente herramientas de piedra), su descubrimiento causó una sensación tanto entre antropólogos de la época como entre el público en general. Sin embargo, esta historia tendría un giro inesperado. En 1986, cuando el acceso a la región se hizo más fácil, los Tasaday fueron declarados un fraude por parte de varios antropólogos, quienes concluyeron que los Tasaday no existían como grupo étnico, sino que era gente de grupos vecinos que habían sido pagados para vivir en las cuevas y adoptar una vida de "cavernícolas" para que el gobierno del dictador filipino, Marcos, pudiera declarar una reserva en la región (los paralelos con el caso Lacandón son múltiples). Sin embargo, la polémica sigue, porque algunos antropólogos ahora mantienen que los Tasaday representan un grupo genuino y distinto a sus vecinos.

${ }^{10}$ Es importante señalar que los "lacandones" representados en esta fiesta tzeltal no son los antepasados directos de los lacandones actuales, sino los lacandones choltís que habitaban la isla de Lacan-tún (Laguna Miramar) que tenían fama de ser muy guerreros, atacando periódicamente las reducciones de indígenas "cristianos" asentados en la franja occidental de la selva. Sin embargo, es significativo que los bachajontecos se refieran a estos "lacandones" como "caribios" (o caribes), asociándolos así con los lacandones actuales (ver más adelante en este artículo la sección "Orígenes dudosos"). Para una descripción y análisis del carnaval de Bachajón véase De Vos (1980: 232-243) y el video de Mariano Estrada (1998).

${ }^{11}$ Cabe mencionar que en el caso de aquellos que escribieron acerca de los lacandones en la primera mitad del siglo xx, no parecía impreciso hablar de la "extinción" de los lacandones, debido a su número muy reducido, en parte como resultado de las enfermedades que trajeron los monteros y chicleros a principios del siglo xx. La fiebre amarilla, en particular, afectó seriamente a la población lacandona en la última década del siglo XIx (véase Baer y Merrifield, 1972). A principios de la década de 1950, Frans Blom llevó a cabo un censo de los lacandones, concluyendo que no llegaban a 200 individuos (Blom y Duby, 1957, citado en Aubry e Inda, 1983: 333). No obstante, esta representación de un grupo al borde de la extinción sigue reproduciéndose hasta hoy en día, aunque existen alrededor de 850 individuos lacandones actualmente, el cual representa un crecimiento demográfico de más de 400 por ciento en 50 años — nada despreciable.

${ }^{12}$ Desde luego, esta idea acerca del "uso etnográfico" de ciertos grupos indígenas en México, donde el estudio de prácticas contemporáneas dan pistas valiosas para reconstruir realidades 
prehispánicas, no ha sido exclusiva a los estudios sobre los lacandones, pero quiero argumentar que ha sido un enfoque particularmente dominante en este caso y, por consecuencia, ha llegado a impregnar muchas representaciones en otros ámbitos. Los lacandones fueron denominados mayas "puros" y "más mayas" que otros grupos mayas del sureste de México, resulta significativo que su lengua se designa como maya lacandón, no simplemente "lacandón".

${ }^{13}$ El descubrimiento de Bonampak causó mucha sensación en México, por lo que los lacandones súbitamente recibieron mucha atención por parte de los medios de comunicación. Frans Blom llamó este fenómeno "Bonampakitis" y en la Biblioteca Fray Bartolomé de Las Casas de Na-Bolom existe una colección de recortes de notas periodísticas compilada por Blom al respecto.

${ }^{14}$ Véase también Piña Chan, 1961, y Anguiano, 1968.

${ }^{15}$ Para más sobre estos proyectos creativos y un análisis de esta "visión arqueológica" de los lacandones en el marco del creciente turismo en la región, véase Köhler y Trench, 2004.

${ }^{16}$ La Fototeca de Na-Bolom conserva alrededor de 50000 negativos de fotografías tomadas por Gertrude Duby. Se estima que 60 por ciento de éstas tratan de los lacandones (Ian Hollingshead; comunicación personal).

${ }^{17}$ Chank'in Viejo murió en 1996, pero se acordaba de "Don Alfredo" (Alfred Tozzer), cuyo informante principal había sido el padre de Chank'in. Los trabajos de Bruce, Boremanse y McGee se basaron, en gran medida, en los testimonios de este líder espiritual de Nahá (véase bibliografía).

${ }^{18}$ Nations y Nigh identificaron 56 especies de cultivos en las milpas lacandonas (1980: 10-11) y 57 especies útiles en los acahuales (1980: 16-17).

${ }^{19}$ Véase http://www.ci-mexico.org.mx/estrategiaconjunta/ anexo1. Para clarificar, no quiero poner en duda la sustentabilidad de la milpa lacandona "tradicional", sino señalar los peligros de asociar las prácticas agrícolas sustentables exclusivamente con un pasado "tradicional", negando, de manera implícita, la posibilidad de encontrar prácticas sustentables e innovadoras entre otros grupos en la región. Sin embargo, tal vez existan elementos de la práctica "tradicional" lacandona que se pueden aplicar al contexto actual. Véase, por ejemplo, el trabajo de Levy y Golicher (2004) que examina el uso de la Ochroma pyramidale en la restauración de algunos acahuales lacandones.

${ }^{20}$ También es significativo que este artículo esté ilustrado con fotografías de lacandones tomadas por Gertrude Duby en las décadas de 1950 y 1960, agregando así una dimensión visual a esta representación anacrónica.
${ }^{21}$ Karl Sapper (1907) fue la primera persona en avanzar esta hipótesis y distinguir entre los lacandones actuales y aquellos "lacandones" choltís que habían resistido a los españoles hasta finales del siglo XVII (De Vos, 1980: 22). Pero esta idea no se popularizó en México hasta las investigaciones de Jan de Vos (1980; 1995). Después siguieron un número de textos en español afirmando lo mismo (véase Garfías y Turok, 1983; Aubry e Inda, 1983; y Aubry, 1987).

${ }^{22}$ Es de interés que Tozzer (1907) comenta que los lacandones del grupo norte se referirían a sí mismos como "masewal", palabra de origen náhuatl, indicando tal vez su interacción con los mexicas antes de la llegada de los españoles (y su presencia anterior en la península de Yucatán donde todavía se usa el término). Véase también Petryshyn (1973).

${ }^{23}$ Existen varias hipótesis acerca del origen de los lacandones actuales y el grado de fusión cultural que ocurrió en la selva Lacandona durante la época colonial que varían levemente entre sí (véase, por ejemplo, Sapper, 1907; Thompson, 1938, 1970, 1977; Scholes y Roys, 1948; Villa Rojas, 1967a; Hellmuth, 1972; Marion 1999). La falta de espacio no permite una discusión extendida de este enigma histórico. Sólo basta señalar que ningún estudio etnohistórico es definitivo (Wilk, 1999) y que existen evidencias de la presencia de hablantes yucatecos ("caribes") en la selva Lacandona en 1646 en una comunidad llamada Noh-há, aunque De Vos concluye que éstos no fueron los antepasados de los lacandones contemporáneos (1980: 215-220). Sin embargo, es importante enfatizar que la identificación de relaciones de parentesco (o su ausencia) entre estas comunidades históricas y los lacandones actuales a través de los archivos existentes permanece como una actividad especulativa.

${ }^{24}$ Véase, por ejemplo, Garfías y Turok, 1983; Aubry e Inda, 1983; y Aubry, 1987.

${ }^{25}$ Otro "giro" a este mismo argumento se encuentra en un boletín de prensa emitido por el Centro de Derechos Humanos Fray Bartolomé de Las Casas, enero de 2003, en el contexto del conflicto actual respecto a tierras disputadas dentro de la Reserva de Montes Azules y la Comunidad Lacandona. En este documento se argumenta que los "neolacandones" no tienen "el arraigo que sirvió de justificación para otorgarles la tierra, no trabajan la zona. Nunca pudieron demostrar títulos primordiales ni restos de poblados que los acreditasen como descendientes de los habitantes ancestrales" (www.ciepac.org/otras20temas/monteazul/ selvazul.htm). Uno se pregunta cuáles "títulos primordiales" podrían haber mostrado los lacandones actuales, dado que 
sobrevivían en la periferia de la colonia española y también cuáles "restos" de sus poblados se esperaba que los lacandones mostraran, dado que era una población altamente móvil: ¿montículos? Además, cabe destacar que este argumento demuestra poco reconocimiento de los aprovechamientos no agrícolas del medio ambiente selvático, como la caza y la recolección.

${ }^{26}$ Cabe mencionar que los lacandones con quien yo he hablado acerca de este tema, rechazan la idea de que sus antepasados se originaron en la península yucateca. Con razón, se identifican como chiapanecos, aunque sí existe la idea entre los lacandones que los grupos meridional y septentrional tienen orígenes distintos.

${ }^{27}$ La cantidad de recursos invertidos en la promoción del ecoturismo en Lacanjá Chansayab en años recientes es llamativa. Yo calculo que en los últimos cinco años alrededor de 12 millones de pesos han sido invertidos en la promoción del turismo en esta comunidad de 550 personas, provenientes tanto de fuentes gubernamentales (principalmente de SECTUR, INI y SEDESOL) COMO de privadas.

${ }^{28}$ Esta campaña se repitió en septiembre de 2004 con el mismo formato.

${ }^{29}$ Cabe mencionar que ha habido un claro rechazo de este estereotipo de los lacandones en otras fuentes mediáticas. Por ejemplo, en un documento elaborado por el Colectivo de Análisis de la Región Selva, titulado Crónica de los Argumentos Históricos y Preparativos a un Desalojo más que Anunciado, se afirma que "los Caribes ya no trabajan su tierra [...] ya no conocen cómo es que la tierra se trabaja y han olvidado sus plantas y su memoria como Pueblo [...] sí cazan pero para traficar con la carne, piel y otras partes de la fauna local". Asimismo, CAPISE, en su Informe Montes Azules (2002), dice que "los caribes se dedican a la caza y a la pesca para vender a los demás indígenas la carne” (p. 17).

${ }^{30}$ De alguna forma, los lacandones (sobre todo las mujeres) se representan a sí mismos todo el tiempo, al realizar figuras lacandonas en madera y barro, principalmente para su venta a turistas. Un análisis de esta actividad sería interesante, pero lo dejo para otra ocasión al no considerarla una actividad que desafía las imágenes dominantes.

${ }^{31}$ Entrevista realizada para el documental "La Última Palabra" en abril 2001 (Serra, 2003).

\section{Bibliografía}

Amram, David W., 1947, "The Lacandon, Last of the Maya", en Pedro R. Hendrichs (ed.), El México antiguo, Vol. VI: 15-30, México.

Anguiano, Raúl, 1968, Aventura en Bonampak: Diario de un Viaje Extraordinario por la Selva Lacandona, Novaro, S.A., México.

Aubry, Andrés, 1987, “¿Quienes son los lacandones? Examen del acervo documental del Archivo Histórico Diocesano de San Cristóbal de Las Casas", INAREMAC, Apuntes de Lectura 7 (09/87), San Cristóbal de Las Casas.

—, y Angélica Inda, 1983, "Cinco antítesis sobre los lacandones: bibliografía clasificada”, en Ochoa y Lee (eds.), Antropología e historia de los mixe-zoques y mayas, unAm-Brigham Young University, México, pp.320-345.

Baer, P. y W. R. Merrifield, 1972, Los Lacandones de México: Dos Estudios, INI, Serie de Antropología Social, 15, México.

Blom, Frans y Oliver Farge, 1926 \& 1927, Tribes and Temples (2 vols.), Middle American Research Institute, Publication Núm.1, Tulane University, New Orleans.

-, and Gertrude Duby, 1955 \& 1957, La Selva Lacandona: Andanzas Arqueológicas, (2 vols), Editorial Cultura, T. G. de S. A., México.

Boremanse, Didier, 1998, Hach winik: The Lacandon Maya of Chiapas, Southern Mexico, Institute for Mesoamerican Studies, University of Texas Press, Albany, N.Y.

Bruce, Robert D., 1967, "Jerarquía maya entre los dioses lacandones," Anales del Instituto Nacional de Antropología e Historia, vol. 18, México.

- 1968, Gramática del Lacandón, Departamento de Investigaciones Antropológicas, Pub. 21, INAH-SEP, México.

-, 1974, ElLibro de Chan K'in, INAH, México, D. F.

—, 1975 y 1979, Lacandon Dream Symbolism (2 Vols.), Euroamericanas Klaus Thele, México.

—, 1976, Textos y dibujos lacandones de Nahá,, INAH, México.

—, 1977, "The Popol Vuh and the Book of Chan K'in", Estudios de la Cultura Maya, vol. X, México.

Caso-Mier, Vicente, 1935, "Among the Lacandones", Three Americas, Vol. 1, Núm. 5, pp. 10-14.

Castañeda, Quetzil, 1996, In the Museum of Mayan Culture: Touring Chichén Itrá, University of Texas Press, Austin.

Chank'in Najbor, Pablo, Axel Köhler y Tim Trench, 2001, Más de mil años después..., Video (Mini DVD), 19’30” min., 
maya lacandón con subtítulos en español e inglés, PVIFSCIESAS, San Cristóbal de Las Casas, Chiapas.

Charnay, Desire, 1888, The Ancient Cities of the New Worldbeing Voyages and Explorations in Mexico and Central America from 1857-1882, Harper and Brothers, New York.

Clifford, James, 1988, The Predicament of Culture: Twentieth Century Ethnography, Literature and Art., Harvard University Press, Cambridge, Mass.

—, y George E. Marcos (comps.), 1986, Writing Culture: The poetics and the politics of ethnography, University of California Press, Berkeley.

Conklin B. and L. Graham, 1995, "The shifting middle ground: Amazonian Indians and eco-politics", American Anthropologist 97: 695-710.

De Vos, Jan, 1980, La paz de Dios y del Rey. La conquista de la Selva Lacandona, Colección Ceiba, Gobierno del Estado de Chiapas, México.

—, 1995, "El Lacandón: Una introducción histórica", en Viqueira y Ruz (eds.), Chiapas: Los rumbos de otra historia, unAM, México.

—, 2002, Una Tierra para Sembrar Sueños: Una Historia Reciente de la Selva Lacandona, 1950-2000, Fondo de Cultura Económica-CIESAS, México.

_, (comp.) 2003, Viajes al Desierto de la Soledad: Un retrato bablado de la Selva Lacandona, Segunda edición, Miguel Ángel Porrúa- CIESAS, México.

Diario Oficial de la Federación, 6/3/72, "Resolución sobre reconocimiento y titulación a favor del núcleo de población Zona Lacandona, municipio de Ocosingo, Chiapas, de una superficie de seiscientos catorce mil trescientas veintiuna hectáreas de terrenos comunales", pp. 10-13.

-, $8 / 3 / 79$, "Resolución sobre reconocimiento de derechos agrarios comunales en el núcleo de población denominado 'Zona Lacandona', municipio de Ocosingo, Chiapas", pp. 40-45.

Duby, Gertrude, 1944, Los Lacandones: Su Pasado y Su Presente. Biblioteca Enciclopédica Popular Núm. 30, Secretaría de Educación Pública, México.

Estrada Aguilar, Mariano, 1998, Lo'bil K’in (La Fiesta de Burla), Video (S-VHS), 18 minutos, tzeltal y español, CDLI-Xi'nich, Palenque, Chiapas.

Fabian, Johannes, 1983, Time and the Other: How Anthropology Makes its Object, Columbia University Press, New York.

Friedlander, Judith, 1986, “The National Indigenist Institute of Mexico Reinvents the Indian: the Pame Example", American Ethnologist, 13 (2): 363-367.
Garfias Ruiz, Gerardo y Marta Turok, 1983, "Los lacandones: Un mito de la Reforma Agraria”, en Ochoa y Lee (eds.) Antropología e Historia de los Mixe-Zoques y Mayas, UnAm Brigham Young University, México, pp. 441-447.

Graburn, Nelson, 1989, “Tourism as a Sacred Journey”, en Valerie Smith (ed.) Hosts and Guests: The Anthropology of Tourism, Segunda edición, University of Pennylvania Press, Philadelphia.

Greenwood, Davyd J., 1989, "Culture by the Pound: An Anthropological Perspective on Tourism as Cultural Commoditization" en Valerie Smith (ed.) Hosts and Guests: The Anthropology of Tourism, Segunda edición, University of Pennylvania Press, Philadelphia.

Hellmuth, Nicholas, 1972, "Progreso y notas sobre la investigación etnohistórica de las tierras bajas mayas de los siglos XVI a XIX", América Indígena, vol. XxxII (1), pp. 179244.

Hervik, Peter, 1999, “The Mysterious Maya of National Geographic", Journal of Latin American Anthropology 4 (1): 166-197.

Instituto Nacional de Ecología/ Secretaria del Medio Ambiente, Recursos Naturales y Pesca, 2000, Programa de Manejo: Reserva de la Biosfera Montes Azules, INE, México.

Ivanoff, Pierre, 1967, "The Tribe that Turned its Back", The Geographical Magazine, vol. XI, núm. 3, pp. 178-185.

Köhler, Axel y Tim Trench, 2004, "Medios y Mimesis en el Mundo Maya", Anuario 2002, CESMeCA-UnICACH, Tuxtla Gutiérrez, Chiapas.

Levy Tacher, Samuel I. y John D. Golicher, 2004, "How predictive is traditional ecological knowledge? The case of the Lacandon Maya fallow enrichment system", Interciencia, 29 (9): 496-503.

MacCannell, Dean, 1976, The Tourist: A New Theory of the Leisure Class, Schocken, Nueva York.

Maler, Teobert, 2003 [1903], "Una visita al lago Pethá, 1898”, traducido y reproducido en Jan de Vos (comp.) Viajes al desierto de la soledad: Un retrato hablado de la Selva Lacandona, Segunda edición, Miguel Ángel Porrúa-CIESAS, México, pp. 139-158.

Margain, Carlos, 1972 [1951], Los Lacandones de Bonampak, SEP Setentas, Núm. 34, México.

Marion, Marie-Odile, 1991, Los Hombres de la Selva: Un Estudio de Tecnología en Medio Selvático, INAH, Colección Regiones de México, México.

—, 1997, Entre Anhelosy Recuerdos, INAH -Plaza y Valdés, México. 
—, 1999, ElPoder de las Hijas de Luna, INAH-CONACUlta-Plaza y Valdés, México.

—, 2000, "Bajo la Sombra de la Gran Ceiba: La Cosmovisión de los Lacandones", Desacatos, 5: 45-56.

McGee, R. Jon, 1990, Life, Ritual and Religion among the Lacandon Maya, Southwest Texas State University, Wadsworth Publishing Company: Belmont, CA.

—, 1997a, "Narrative Structure of Lacandon Creation Mythology", Latin American Indian Literatures Journal, 13 (1): 1-22.

—, 1997b, "Natural Modelling in Lacandon Maya Mythology", en Frank A. Salamone y Walter R. Adams (eds.), Explorations in Anthropology and Theology, University Press of America, Inc., Nueva York, pp. 175-190.

_, 2002, Watching Lacandon Maya Lives, Allyn and Bacon, Boston, MA.

Na-Bolom A. C.-Ecosur, 2000, Memoria Lacandona, CD-Rom, San Cristóbal de Las Casas, Chiapas.

Nations, James D., 1979, «Population Ecology of the Lacandon Maya», Tesis de doctorado en antropología social sin publicar, Southern Methodist University, Dallas, Texas.

—, and Ronald B. Nigh, 1980, "The evolutionary potential of Lacandon Maya sustained-yield tropical forest agriculture", Journal of Anthropological Research, 36 (1).

Ortela Francisco, Juan Carlos, 2001, El balché, bebida ritual lacandona, Video (S-VHS), 25 min., CELALI, San Cristóbal de Las Casas.

Paladino, Stephanie, 1996, What is a Lacandon?: Changing Images, Changing Opportunities, Rights, Resources and Actions, Documento inédito, Universidad de Georgia, E. U.

Perera, V. and R.D. Bruce, 1982, The Last Lords of Palenque: The Lacandon Mayas of the Mexican Rain Forest, University of California Press, Berkeley.

Petryshyn, J. T. "Caribs, Lacandons, Lacantun, Maséwal or Masséwal?”, Presentación en la xxi Congreso Anual de la American Society for Ethnohistory, Edmund, Oklahoma, E. U., pp. 5 (disponible en la Biblioteca Fray Bartolomé de Las Casas, Na-Bolom, A. C., San Cristóbal de Las Casas, Chiapas).

Piña Chan, Román 1961 Bonampak INAH, México.

Rorty, Richard, 1980, Philosophy and the Mirror of Nature, Princeton University Press, Princeton, NJ.

Said, Edward, 1978, Orientalism, Penguin, Londres.

Sapper, Karl, 1907, "Choles und Chorties", en Publications du Congres International des Américanistes, XV session, Québec,
1906, vol. II, pp. 423-439, Québec, Canadá, Una versión en español está disponible en: Axel Köhler y Víctor Manuel Esponda Jimeno (eds.), 2004, "Choles y Chorties de Karl Sapper, 1907”, Liminar, Estudios Sociales y Humanisticos, Año 2, vol. II, Núm. 1, pp. 114-142.

Serra, Grau, 2003, La Última Palabra, Video-documental, VHS, 48 min., Grau Serra/ Milana Bonita S. L., Barcelona.

Scholes, F.V. and R.L Roys, 1948, The Maya Chontal Indians of Acalan-Tixchel: A Contribution to the History and Ethnography of the Yucatan Peninsula, Carnegie Institute, Washington, Publication 560, University of Oklahoma Press, Norman, Oklahoma.

Slater, Candace, 1995, "Amazonia as Edenic Narrative", en William Cronin (ed.) Uncommon Ground. Rethinking the Human Place in Nature, W.W. Norton, pp. 114-131, Nueva York y Londres.

Soustelle, Jacques, 1971 [1936], México, Tierra India, Traducción por Rodolfo Usigli, Secretaría de Educación Pública, México.

Stephens, John L., 1969 [1841 \& 1843], Incidents of Travel in Central America, Chiapas and Yucatan, Dover Publications, New York.

Thompson, J. Eric, 1938, Sixteenth and seventeenth century reports on the Chol Mayas", American Anthropologist, 40 (9), pp. 584-603.

—, 1970, Maya History and Religion, University of Oklahoma Press, Norman, Oklahoma.

—, 1977, "A Proposal for Constituting a Maya Subgroup, Cultural and Linguistic, in the Petén and Adjacent Regions", en G. Jones (ed.) Anthropology and History of Yucatan, University of Texas Press: Austin, pp. 3-42.

Tozzer, Alfred M., 1907 A, Comparative Study of the Mayas and the Lacandones, Macmillan \& Co., New York.

Trench, Tim, 2002, "Conservation, Tourism and Heritage: Continuing interventions in Lacanjá Chansayab, Chiapas, Mexico", Tesis de doctorado, inédito, Departamento de Antropología Social, Universidad de Manchester, Inglaterra.

Turner, Terence, 1992, “Defiant Images: The Kayapó Appropriation of Video", Anthropology Today 8(6): 5-16.

Urry, John, 1990, The Tourist Gaze: Leisure and Travel in Contemporary Societies, Sage, London.

—, 1995, Consuming Places, Routledge, London.

Van den Berghe, P.L. and Charles F. Keyes, 1984, "Tourism and Re-Created Ethnicity", Annals of Tourism Research, 11: 343-352. 
Villa Rojas, Alfonso, 1967a, "Los Lacandones: su origen, costumbres y problemas, vitales", in América Indígena, 27 (1): 25-53.

—, 1967b, "Los Lacandones: recursos económicos y organización social”, in América Indígena, 27 (3): 461-494.

—, 1968, "Los Lacandones; sus dioses, ritos y creencias religiosas", in América Indígena, 28 (1): 81-138.

—, 1982, "Introducción" en Alfred Tozzer Un estudio comparativo: mayas y lacandones. México, INI.
Viqueira, Juan Pedro, 1995, "La Comunidad India en México en los Estudios Antropológicos e Históricos." Anuario 1994. Tuxtla Gutiérrez, Chiapas: CESMECA-UNICACH.

—, y Mario Humberto Ruz (eds.), 1995, Chiapas: Los Rumbos de Otra Historia. México, UNAM/CIESAS.

Wilk, Richard R., 1999, 'Whose Forest? Whose Land? Whose Ruins? Ethics and Conservation", Science and Engineering Ethics, 5(3), 367-374. 